\title{
Sustainability reporting and assurance: A historical analysis on a world-wide phenomenon
}

\author{
Renzo Mori Jr. \\ University of Southern Queensland
}

\author{
Peter J Best \\ Griffith University \\ Julie Cotter \\ University of Southern Queensland
}

ABSTRACT. Sustainability reporting and assurance for sustainability reports have been used by organisations in an attempt to provide accountability to their stakeholders. A better understanding of current practices is important to provide a base for comparative and trend analyses. This paper aims to consolidate and provide information on sustainability reporting activities, assurance for sustainability reports practice and types of assurance providers. Another aim of this paper is to provide a historical perspective of these themes, summarize and compare previous studies, and suggest opportunities for future research. To accomplish these objectives, a literature review was performed, and an analysis of the organisations included in the Fortune Global 5002010 was completed and general results were presented and consolidated by country. These results demonstrate that all organisations analysed provided some type of information in relation to their social or environmental performance in their official website. The percentage of organisations issuing a formal sustainability report has been increasing in the last few years. However, the percentage of organisations assuring their sustainability report is stagnate. Types of assurance engagements include those performed by accountants and consultants, but new practices have emerged, namely the "mixed approach" and the "stakeholder or specialist review". The analysis also shows that the practices of issuing sustainability reports and having them assured have become a world-wide phenomenon, occurring in developed and emerging economies around the world. 
KEY WORDS: sustainability reporting, sustainability reports, sustainability report assurance and assurance providers.

\section{Introduction}

The transformation in the way business is conducted since the late 1980s and early 1990s, allied to the increasing relevance of the sustainability concept in a globalized scenario, has changed the business world (Moneva, J. et al. 2006; Perego 2009; Phatak et al. 2005). Through a survey of 1,946 executives representing a wide range of industries and regions,McKinsey \& Company (2010), found that more than 50 percent of executives consider sustainability "very" or "extremely" important in their business practices.

In this context, sustainability reports have been working as a fundamental communication tool between organisations and their stakeholders, notably about organisations' environmental and social performance. According to KPMG (2008) close to 80 percent of the top 250 organisations listed at the Fortune Global 500 ranking (G500) issued a type of sustainability report.

According to previous studies, the most used sustainability report guideline to date is the Global Reporting Initiative (GRI) (Borglund et al. 2010; Brown et al. 2009; KPMG Global Sustainability Services 2008). KPMG (2008) found that 77 percent of the top 250 organisations on the Fortune Global 500 applied GRI's guidelines for their sustainability reporting.

Fortune Global 500 is an annual ranking of the top 500 corporations worldwide measured by revenue and it is prepared and published by Fortune Magazine. Fortune Global lists have been used by previous studies related to sustainability reporting and assurance for sustainability reports (Kim \& Nam 2011; Kolk 2009; Kolk \& Perego 2010; KPMG Global Sustainability Services 2008; Rikhardsson et al. 2002).

In order to enhance credibility and reliability of sustainability reports, some organisations commenced to voluntarily include external independent assurance in their sustainability reports. As 
assurance of sustainability reports is a relatively new practice and not regulated in a majority of countries, different types of entities are providing assurance services using different scopes, methodologies and assurance statements (Deegan et al. 2006; Fedération des Experts Comptables Européens 2006; Frost \& Martinov-Bennie 2010; KPMG Global Sustainability Services 2008; Moneva, J. et al. 2006; O'Dwyer \& Owen 2005; Owen et al. 2009; Perego 2009; Romero et al. 2010).

Previous authors have independently studied sustainability reporting activities, the assurance of sustainability reports, and types of assurance providers in different countries and over different periods of time based on different samples. Due to those differences, updated and consolidated information about those practices is important to provide a base for comparative and trend analyses. In order to mitigate those differences, this paper presents updated information about current sustainability reporting activities, assurance practices for sustainability reports and types of assurance providers for the organisations on the Fortune Global 500, 2010. In addition, this paper performs comparative analyses with relevant previous studies regarding these issues, and proposes opportunities for further research...

\section{Literature Review}

\subsection{Sustainability Reports}

Society's increasing awareness about environmental and social issues, climate change, sustainable supply chain management, natural disasters and scarcity of natural resources has contributed to a transformation in the way business is conducted (Kolk \& Van Tulder 2010; 2005; Seuring \& Müller 2008).

In this new scenario sustainability reports have been working as a vital tool for organisations to provide transparent communication with their stakeholders, especially about organisations' social 
and environmental performance. Some authors argue that sustainability reports also have been influencing the decision-making processes of different stakeholders, concerned not only with economic aspects but also with environmental and social aspects (Barrett 2005; Futerra Sustainability Communications Ltd et al. 2010; KPMG Global Sustainability Services \& SustainAbility Ltd. 2008). The first wave of organisations publishing their social and environmental impacts started in the 1970s in the United States and Western Europe (Kolk 2009; Owen et al. 2001).

Since the 1970s, there has been considerable diversity in the voluntary publication of sustainability reports across industry sectors and countries The title and scope of such reports have varied considerably, including "sustainability reports", "social reports", "corporate social responsibility reports", "social and community reports" and "environmental reports" (Hubbard 2009; Kolk 2009; Owen et al. 2001).

This paper has adopted the term sustainability report in accordance with the Global Reporting Initiative definition (2011, p. 3): "Sustainability reporting is the practice of measuring, disclosing, and being accountable to internal and external stakeholders for organizational performance towards the goal of sustainable development. A sustainability report should provide a balanced and reasonable representation of the sustainability performance of the reporting organisation, including both positive and negative contributions".

\subsection{Sustainability Report Assurance}

Owing to the relevance of sustainability reports, some stakeholders have questioned the integrity, benefits and transparency of the information published by organisations through sustainability reports (Laufer 2003; Moneva, J. M. et al. 2006; Ramus \& Montiel 2005). In response, various organisations instigated the practice of independent assurance for sustainability. According to O’Dwyer (2005), assurance of sustainability reports commenced in 1997-1998. 
Internal and external stakeholders' demands for transparency and credibility in sustainability reports have driven the development of independent assurance. In its survey of Fortune Global 250, KPMG (2008) found that improved quality of reported information, reinforced credibility among stakeholders and improved reporting processes are the main drivers for seeking assurance of a report.

Hodge, Subramaniam and Stewart (2009) in their study of 145 students enrolled in MBA programs at two large Australian universities, identified that provision of an assurance statement with a sustainability report engenders greater credibility in a report than when no such assurance is provided. In addition, they found that report users place more confidence in sustainability reports when such assurance is provided by a top tier accountancy firm, as opposed to a specialist consultant.

In contrast, Owen, Chapple and Urzola (2009) interviewed senior corporate responsibility managers from ten FTSE100 organisations, and representatives of three key stakeholder groups (investor, NGO and the trade union movement). The authors found that while there is some evidence of stakeholder interest in assurance, notably on the part of NGO, the real driving force behind assurance is internal to an organisation.

The two most famous frameworks for assurance services used by assurers around the world are the AA1000 Assurance Standard (AA1000AS) launched in March 2003 by AccountAbility (Accountability 2011), and the International Audit Assurance Standards Board (IAASB)'s International Standard on Assurance Engagements (ISAE3000). It is also argued that assurance based on the combined use of AA1000AS and ISAE3000 is likely to deliver enhanced results (KPMG Global Sustainability Services \& AccountAbility 2005).

Currently, these two frameworks have been used by two different groups of assurers: accounting professionals and consultants. Consulting firms are likely to rely on the AA1000AS framework and 
accounting organisations tend to rely on ISAE3000 (Deegan et al. 2006; Frost \& Martinov-Bennie 2010; Mock et al. 2007; Moroney et al. 2011; Perego 2009).

The difference between accountants and consultants is not just related to the framework used to perform the assurance service. Hodge, Subramaniam and Stewart (2009) argue that in comparison to accountants, specialist consultants appear to focus more on completeness, fairness and overall balance in the opinion statements. Perego (2009) concludes that accounting firms provide a higher quality of assurance for aspects related to reporting format and procedures used and non-accounting firms provide higher quality of assurance for aspects associated with recommendations and opinions.

Frost and Martinov-Bennie (2010) identified differences among assurance statements issued by assurance providers. They identified differences in the assurance standards used during the assurance process (AA1000AS, ISAE 3000 and firm specific protocols), in the wording of the conclusions, in the title of the assurance statements, in the objectives of the assurance processes and in the assurance procedures employed.

Even though accounting firms and consultants firms have been cited as the two main groups of assurance providers, certification bodies and social/ethical organisations were also considered by previous authors (Frost \& Martinov-Bennie 2010; Owen et al. 2009; Romero et al. 2010).

In addition to the difference among assurance service providers, previous studies have also identified differences in the assurance scope, methodologies and statements (Deegan et al. 2006; Edgley et al. 2010; Frost \& Martinov-Bennie 2010; KPMG Global Sustainability Services 2008; Manetti \& Becatti 2009; O'Dwyer \& Owen 2005; Owen et al. 2009; Romero et al. 2010). For instance, Mock, Strom and Swartz (2007) studied 130 assurance processes from entities worldwide which issued assured sustainability reports between 2002 and 2004 and identified: 
- Different scope: $67 \%$ of the assurers provided complete assurance related to GRI recommended reporting categories, $16 \%$ assured both environmental and social information, while $16 \%$ assured only environmental issues;

- Different methodology: $24 \%$ of the assurers followed the AA1000AS, $18 \%$ followed international standards, $15 \%$ followed local standards and $42 \%$ did not indicate the framework used;

- Different assurance statement: $74 \%$ provided a positive assurance statement, $17 \%$ provided a negative assurance statement and $9 \%$ provided a hybrid statement (positive and negative aspects combined).

\section{Research Methods}

This study examined publicly-accessible information of organisations in the G500, 2010, to determine current practices in the provision of social or environmental information on their websites, the issue of sustainability reports, the assurance of sustainability reports, and the type of assurer used.

The organisations' official website accesses were carried out between 15/09/2011 and 12/10/2011. The website analysis followed the protocol used by Rikhardsson et al. (2002), which considered the amount of time that a regular stakeholder would use to locate social and environmental information of interest. The time limit used in this study was 40 minutes per website.

For the sustainability report analyses, this study considered only reports issued by corporate, holding or global organisations' representatives. Reports issued by affiliates or controlled organisations were not considered. A list of criteria was also established to standardise the sample. To be included in the sample, websites were required to meet the following criteria:

- Contains information about the organisation's social and environmental performance;

- Provides information in the English language; 
- Provides information regarding the organisation's performance in 2010.

This study considered all types of sustainability report, which achieved the paper's criteria as above, regardless of the report title adopted (Environmental and Social Report, Sustainability Report, Ethical Report, etc.).This paper examined assurance of sustainability reports regardless of the scope of assurance services provided and/or independent third party opinions included in the organisations' sustainability reports. The scope of the assurance process and type of the assurance statement provided were not analysed. Sixteen organisations were excluded from the analysis for the following reasons:

- 13 organisations did not provide information regarding sustainability reporting in their official website in the English language;

- 1 organisation did not provide its sustainability report in the English language;

- 1 organisation's official website was not available during the data collection phase;

- 1 organisation did not issue a corporate, holding or global report. In this situation, only affiliates and controlled organisations issued a sustainability report and these reports were not considered in this analysis.

Excluding the exceptions listed above, the sample was composed of 484 organisations. Rikhardsson et al. (2002) has also identified similar exceptions in a previous study.

All information obtained from the organisations' official website and from their respective sustainability reports were consolidated and then a descriptive statistical analysis was conducted. Results summarise the proportion of organisations providing social or environmental information on their websites, issuing sustainability reports, assuring their sustainability reports, and the type of assurer used.

Those results are first presented in a general form, and then presented by country. The Fortune Global 500 list examined by this paper was published online 


\section{Findings}

\subsection{Sustainability reporting}

Organisations have been disclosing their social and environmental performance through sustainability reports in order to meet stakeholders' expectations. All organisations in the sample published on their official website some type of information related to environmental and/or social performance. The percentage of companies which publish social and/or environmental information on their websites has increased when compared with a previous similar study conducted by (Rikhardsson et al. 2002), using the Fortune Global 500 list in 2000 (social information 63\%, environmental information $79 \%$ and both information 55\%). The increased number of organisations providing social and/or environmental information in their websites demonstrates that the internet has been widely used to communicate organisations' environmental and social performance to their stakeholders, as recommended (Rikhardsson et al. 2002).

Figure 1 presents a chronological evolution of the percentage of organisations issuing a sustainability report, considering results from this study and from previous studies (Kolk 2009; KPMG Global Sustainability Services 2008; Rikhardsson et al. 2002).

This study found that $85 \%$ of the sample analysed issued a formal sustainability report, much higher than the $47 \%$ reported by Rikhardsson et al. (2002) (24\% issued a specific environmental report, $18 \%$ an integrated report containing environmental and social information, $3 \%$ issued both, an environmental and a social report, and $2 \%$ issued a specific social report).

Considering just the top 250 of the sample analysed, the percentage of organisations which issued a sustainability report is even higher, 93\%. Even though some authors argue that current 
sustainability reporting processes need improvements and could not have been achieving their purpose (Laufer 2003; Moneva, J. et al. 2006; Ramus \& Montiel 2005), organisations are using this type of report even more to disclosure their social and environmental performance.

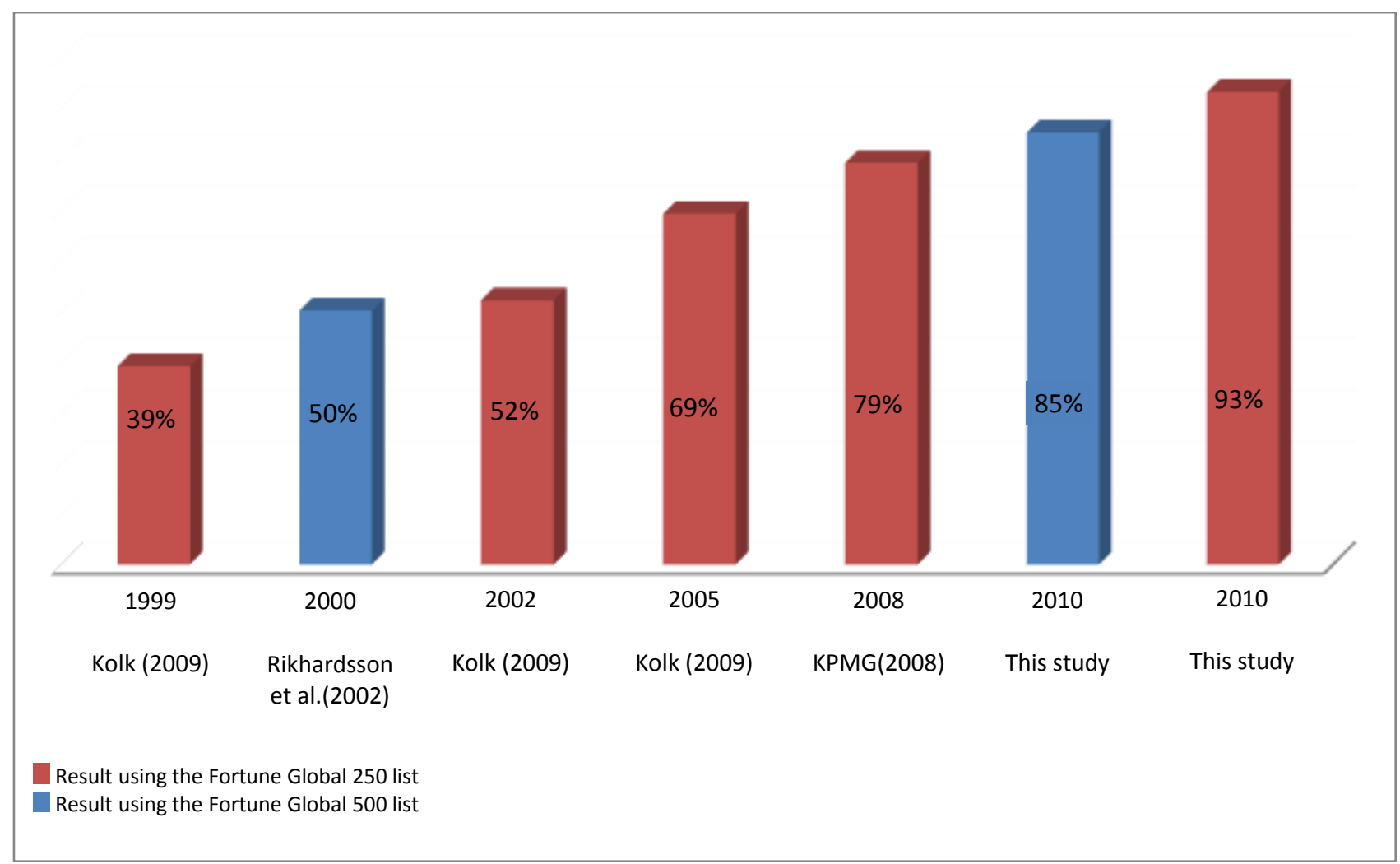

Figure 1: Percentage of organisations in the Fortune Global list which have issued a sustainability report by year.

Showing an analysis by country, Figure 2 presents the percentage of organisations in the sample which have issued a formal sustainability report. Previous studies have considered Japan and European countries more active in sustainability reporting than other developed countries such as: United States, Canada and Australia; and some emerging economies such as: Brazil, China, India and Russia (Kolk 2009; KPMG Global Sustainability Services 2008). Figure 2 demonstrates that China and South Korea, have been increasing their percentage in the last few years, but have not achieved the high level of sustainability reporting already reached by other countries. High levels of sustainability reporting are also evident among some emerging economies, especially India and Brazil, some developed countries such Australia and United States, especially Australia which 
shares the highest level of the countries presented on Figure 2 with Austria, Belgium, India and Sweden.

Of the top five countries with the largest number of organisations in the Fortune Global list which together represent $66 \%$ of the total (U.S., Japan, China, France and Germany), Japan achieved the highest percentage of organisations issuing a sustainability report, followed by U.S, France and Germany that achieved a similar percentage. China achieved the lowest percentage among the five countries.

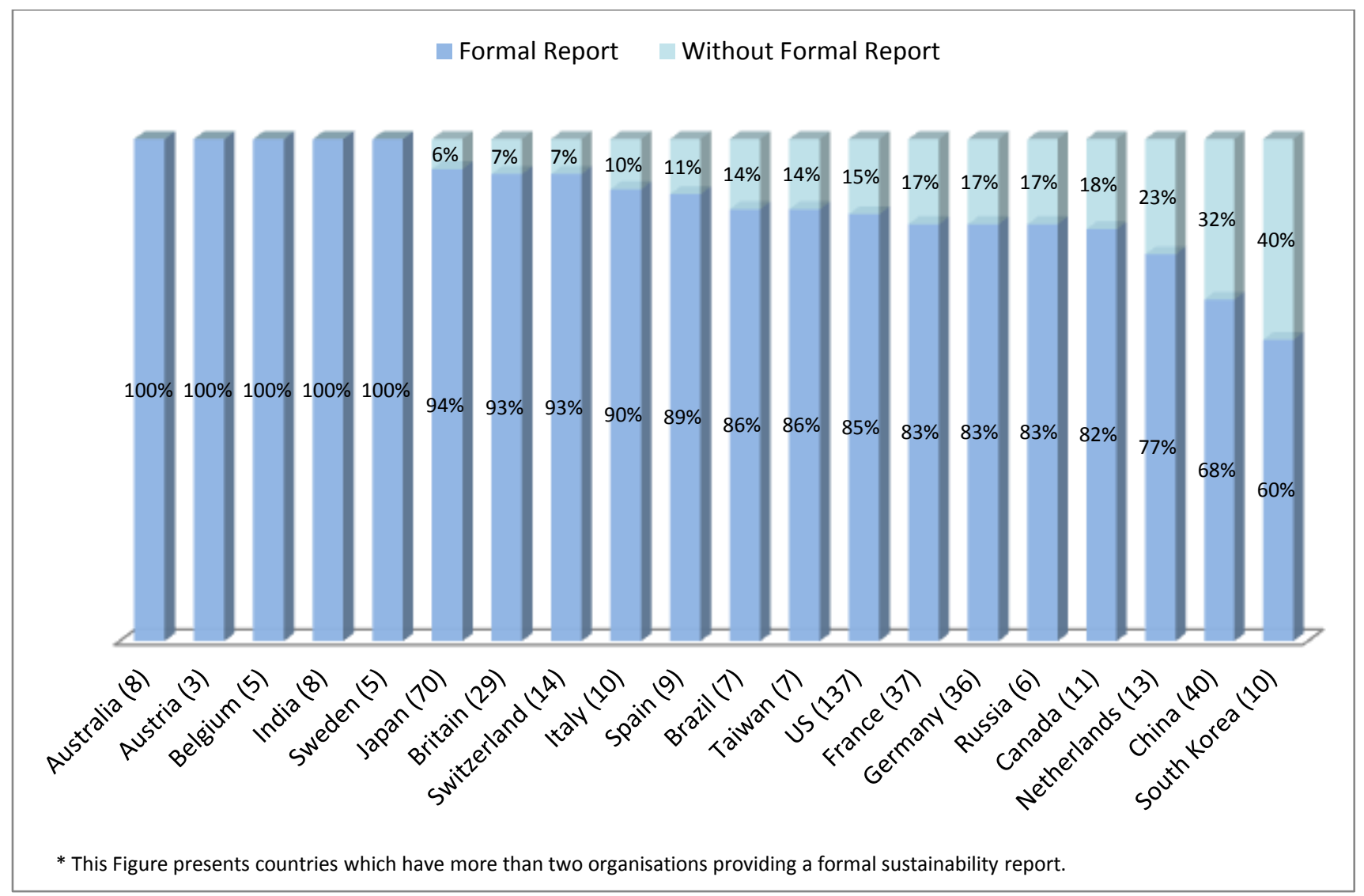

Figure 2: Percentage of organisations in the Fortune Global 500 in 2010 which provided a sustainability report, analysed by country.

The increase in the number of organisations issuing a sustainability report in all geographic regions demonstrates that this is not a local and particular situation but a worldwide phenomenon, occurring in developed and emerging economies around the world. 


\subsection{Assurance of Sustainability Reports}

Some authors argue assurance process for sustainability reports contributes towards an organisation's activities by: improving internal controls; creating more stringent sustainability reports; and helping an organisation to be more transparent and credible to their stakeholders (Dando \& Swift 2003; Fedération des Experts Comptables Eurepéens 2003; Global Reporting Initiative 2011; KPMG Global Sustainability Services \& AccountAbility 2005; KPMG Global Sustainability Services \& SustainAbility Ltd. 2008; Park \& Brorson 2005). However, some authors propose that without strong market regulation for this type of service, the value of the assurance processes and the respective statements published to the market by assurance providers is questionable (Ball et al. 2000; Laufer 2003; Owen et al. 2009; Smith et al. 2011).

Results from this study regarding the percentage of organisations which issued a sustainability report assured are similar to previous studies (Kolk 2008; KPMG Global Sustainability Services 2008; Simnett et al. 2007). Figure 3 indicates that there has been little variation in the percentage of sustainability reports assured since 2002, even with different samples. 


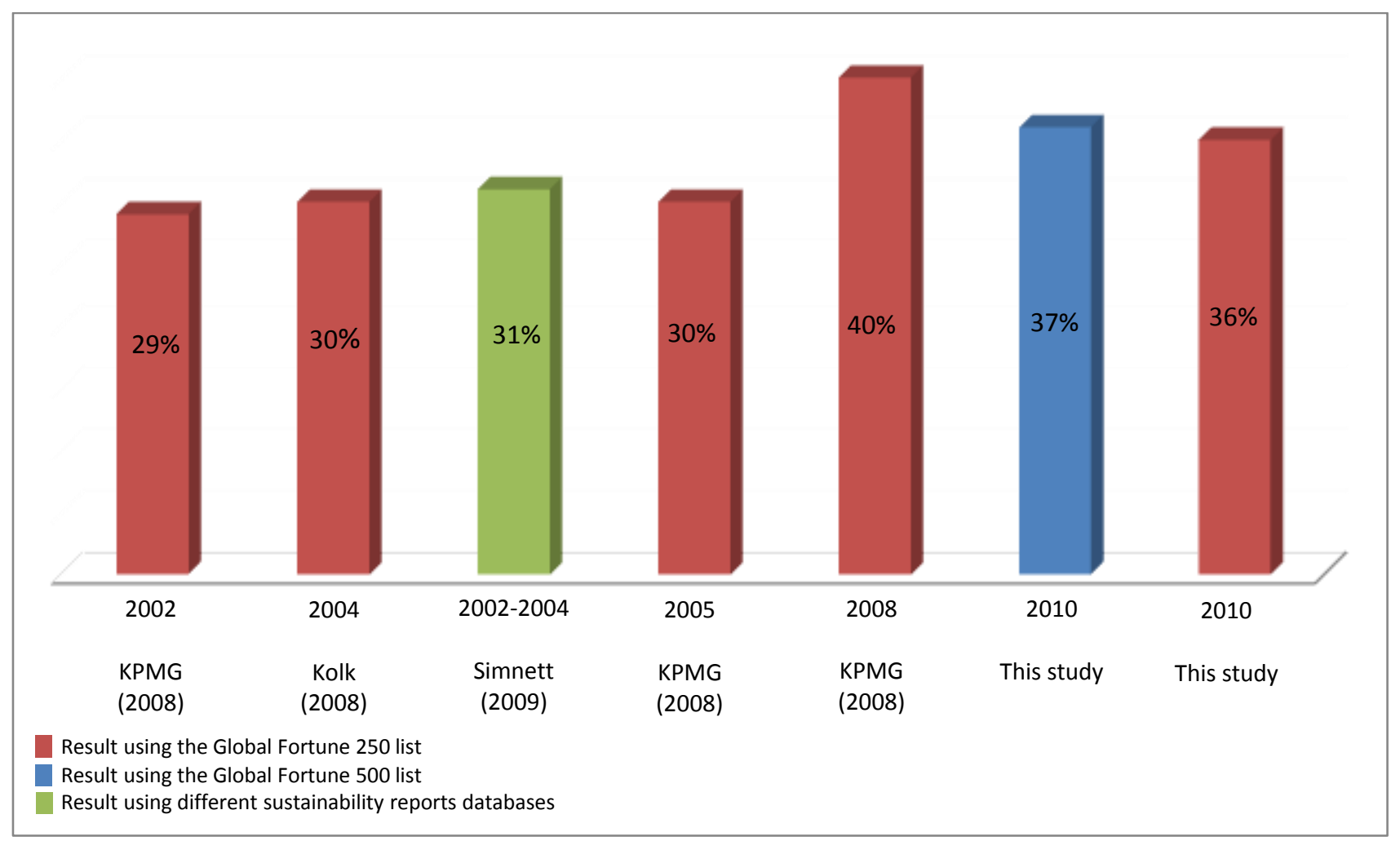

Figure 3: Percentage of organisations which have issued a sustainability report assured by year.

Figure 3 indicates that there has been little increase in the proportion of organisations analysed issuing assured sustainability reports in the past decade. This is despite the growing number of organisations issuing sustainability reports. There appears to be little growth in the perceived value of assurance.

Considering percentage by countries, Figure 4 indicates that Australia, Spain, Netherlands, Italy, Brazil, Britain, Sweden and Japan achieved higher percentage levels of reports assured (more than $50 \%)$. Most of the countries in this group are developed and European countries. There are just two exceptions. The first is a non-developed and non-European country, where Brazil achieved the $5^{\text {th }}$ place with $63 \%$ of the sustainability reports assured. Secondly, Australia, a developed nonEuropean country achieved the best performance, with all sustainability reports assured. In relation to the lower percentage, Austria, South Korea, Taiwan, Canada, Belgium, China and U.S. achieved the mark of less than $35 \%$ of the reports assured. In this group there are developed and emerging 
economies representatives from Asia, Europe and North America.

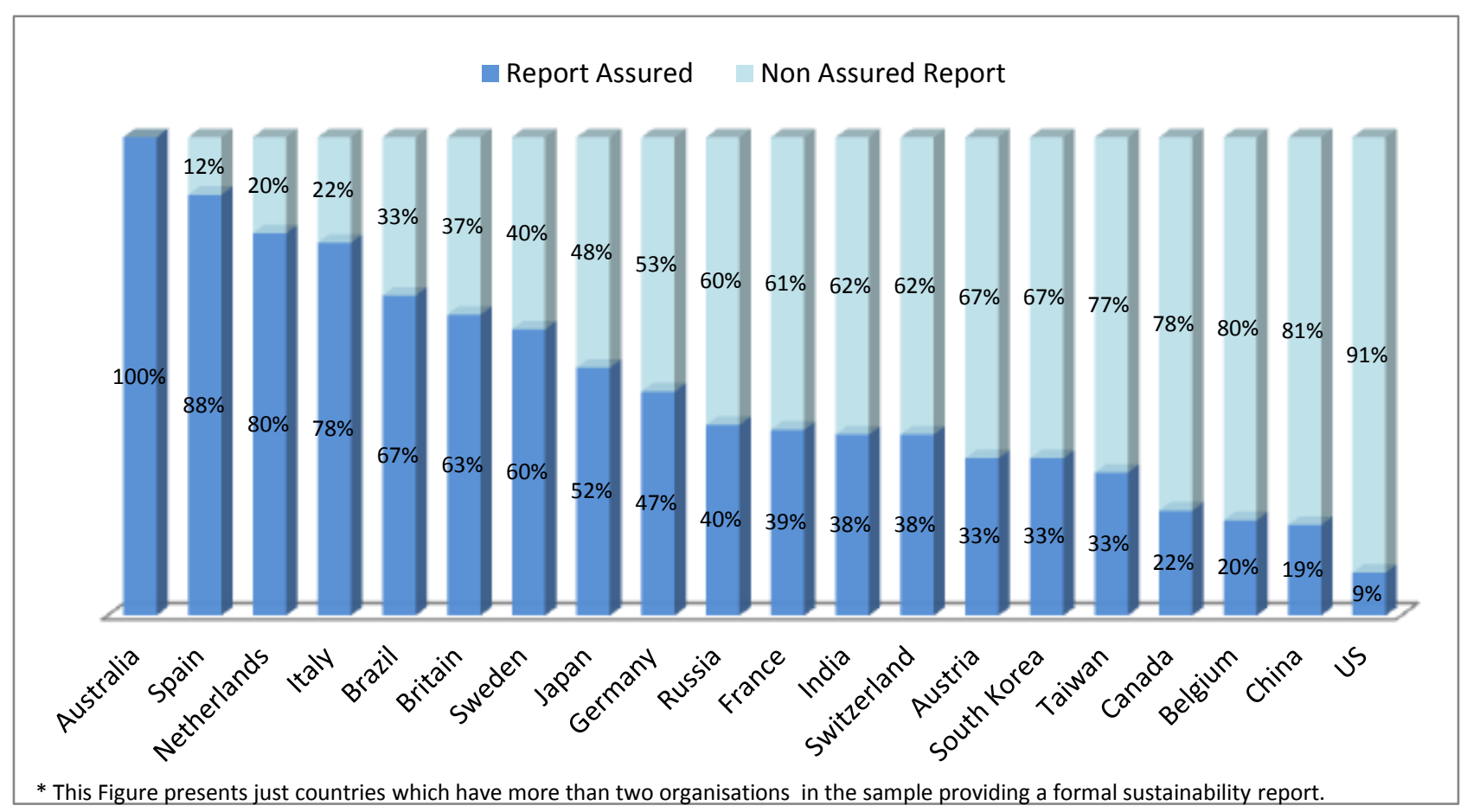

Figure 4: Percentage of sustainability reports assured by country of the organisations included at the Fortune Global list in 2010 .

According to previous studies, external assurance is most prevalent in Japan and Europe and not common in the U.S. (Kolk 2008; Kolk \& Perego 2010). What is new in this study is the percentage of sustainability reports assured in other countries, especially Australia and Brazil. Australia achieved the highest percentage of the sample and Brazil overtook Japan and most of the European countries.

\subsection{Assurance Providers}

Previous studies have reported differences in the type of assurance providers sustainability reports. Two main groups of assurance providers have been identified: accounting firms and consultant firms (Edgley et al. 2010; Hodge et al. 2009; Manetti \& Becatti 2009). Owen, Chapple and Urzola (2009) and Romero, Ruiz and Fernández-Feijóo (2010) considered certification bodies or certifiers' 
representatives as another type of assurance provider However, this study considered certification bodies or certifiers' representatives as consulting firms.

Although an assurance statement is the most common result of an assurance process conducted by accounting and consultant firms, some organisations issued a different type of statement provided by a third party review. This specific third party review practice has been referred to in most of the sustainability reports analysed as a "Third Party Comment" or a "Third Party Review", and it is provided by different entities such as: stakeholder panels; presidents and directors of international institutes and international organisations; university specialists operating in the sustainability reporting area; and others. In this study this specific practice is called "Stakeholder or Specialist Review".

This study identified that $16 \%$ of the organisations which issued a sustainability report assured have included a third party review statement. This statement does not share the features of assurance statements issued by accounting firms and consulting firms. However, this statement is also intended to provide a public independent opinion about the quality of the sustainability report published, the information contained in it and in some cases, recommendations to improve the quality of the sustainability report. A summarised description of stakeholder or specialist reviews was provided by KPMG (2008), which identified that $27 \%$ of the organisations listed at Fortune Global 250 used third party comments from people who were not professional assurance providers.

Some organisations in this study adopted "Mixed Approach" to assurance services. This mixed approach uses different groups of assurance providers in the same sustainability report (accounting and consulting firms or accounting firms and stakeholder or specialist reviewers). In this situation, each entity reviews a specific area of the report and issues a specific statement, and both statements are included on the organisation's sustainability report. 
This study found that $56 \%$ of the statements issued in the sample were provided by accounting firms, $26 \%$ by consulting firms, and $16 \%$ by stakeholder or specialist reviewers, with $2 \%$ employing a mixed approach.

Figure 5 summarises he type of assurance providers used by organisations in the sample by country. It is noticeable that third party reviews were used by organisations in Japan, China and Korea, with Japan responsible for $92 \%$ of these cases. The mixed approach was used only in Spain and Japan, and this practice represented almost a third of all sustainability reports issued with an assurance statement in Spain.

Consulting firms have dominance in the sustainability assurance market in Taiwan, U.S, India, Australia and China, while accounting firms perform most assurance engagements in European countries and in Canada, Brazil and Russia.

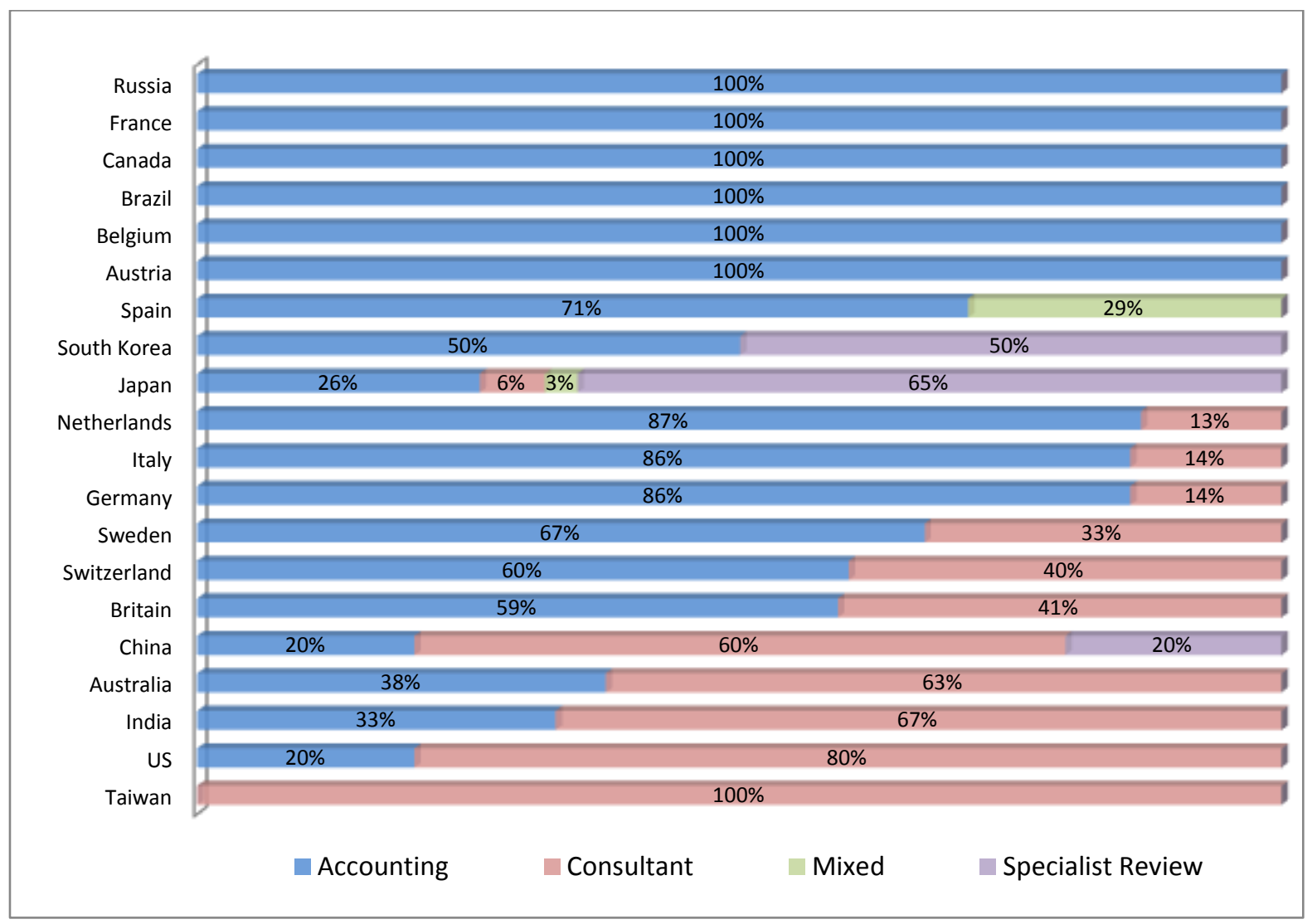

Figure 5: Type of assurance provider by country for organisations in the Fortune Global 500 list in 2010. 
This study achieved similar results to those presented by Romero, Ruiz and Fernández-Feijóo (2010) in Spain, where the majority of the assurance engagements were provided by accounting firms, and Frost and Martinov-Bennie (2010) in Australia, where the majority of the engagements were provided by consulting firms.

Mock, Strohm and Swartz (2007) found that accounting companies do not dominate the global assurance market. However, this study indicates that accounting firms do dominate the assurance market, similar to the results presented by Simnett, Vanstraelen and Chua (2007), KPMG (2008), Kolk (2009), Manetti and Becatti (2009) and Kolk (2008).

\section{Discussion and Conclusions}

This study demonstrates that organisations worldwide are using sustainability reports to provide accountability about their environmental and social performance independent of their geographic location and the level of economic development of the country where they are based.

This study indicates that the number of organisations in the Global Fortune lists issuing a formal sustainability report has been increasing steadily over the past decade, the proportion of sustainability reports which have been assured has not increased signficantly.

The increase in the number of sustainability reports issued could be related to the society's increased awareness of environmental and social issues, and this awareness results in demand for more accountability about organisations' environmental and social performance. Sustainability reporting has also become a compulsory activity in some countries, which could work towards increasing the number of organisations which issued a sustainability report. It is important to highlight that an increase in number does not mean an increase in quality. In order to achieve transparency about their performance, organisations should incorporate and provide information regarding some fundamental aspects of their sustainability reporting process, such as: identification 
and engagement with stakeholders, identification of stakeholders' demands, materiality tests and accountability about all key issues identified.

There is no observable increase in the adoption of assurance engagements amongst organisations in the sample. There are still some questions in the current literature about the real benefits of the assurance process as it is currently being provided. Some academics have strongly questioned the efficacy of the current assurance process in enhancing transparency and accountability to key stakeholder groups. The lack of specific regulation about the assurance process for sustainability reports and the differences among assurance services by different assurance providers could be contributing to these questions.

In order to improve transparency for sustainability reports, the current assurance process must first be transparent in itself. Full versions of the assurance statements with detailed information about the work carried out, results obtained and recommendations must be available, explicit and understandable to stakeholders. Without high level of transparency the assurance process for sustainability reports could be considered just a bureaucratic and non important activity. Additionally users and readers of the sustainability reports must be aware of the different scope of the assurance providers. Realising these differences is very important to understand exactly how much information in the sustainability report is being verified by an independent third party.

The conclusions presented in this study must be moderated by the following limitations. There are significative differences in the number of organisations in each one of the countries analysed, which could affect the results presented in percentage form. Analyses of the organisations' official websites were comprehensive but not exhaustive. The results obtained in this study were based only on information provided through the organisations' official websites.

It is important to highlight that the quality, content, scope and outcomes of the sustainability reports and the assurance processes were not considered. Regarding integrated reports, this study has used 
the same concept adopted by Kolk (2008), where the assurance process has only been counted if this applied specially to the sustainability information.

Despite the limitations inherent to the research methodology, findings and conclusions presented in this paper will contribute to future investigations in the sustainability reporting and assurance areas. Certainly, there are considerable opportunities for further work and we suggest future studies on the following issues: (1) the motivations and benefits of issuing an assured sustainability report; (2) the advantages and disadvantages of different types of assurance services provided by different assurance providers; (3) extending our analysis to larger samples of organisation; and (4) stakeholders' perceptions and understanding regarding the assurance process. 


\section{REFERENCES}

Accountability 2011, AA 1000 Stakeholder Engagement Standard 2011 - Final Exposure Draft.

Ball, A, Owen, D \& Gray, R 2000, 'External transparency or internal capture? The role of third-party statements in adding value to corporate environmental reports1', Business strategy and the environment, vol. 9, no. 1, pp. 1-23,

Barrett, P 2005, Sustainability Reporting - The Role of Auditors, Wellington, New Zealand.

Borglund, T, Frostenson, M \& Windell, K 2010, Increasing responsibility through transparency?

Brown, H, de Jong, M \& Levy, D 2009, 'Building institutions based on information disclosure: lessons from GRI's sustainability reporting', Journal of Cleaner Production, vol. 17, no. 6, pp. 571-80,

Dando, N \& Swift, T 2003, 'Transparency and Assurance Minding the Credibility Gap', Journal of Business Ethics, vol. 44, no. 2, pp. 195-200,

Deegan, CM, Cooper, BJ \& Shelly, M 2006, 'An investigation of TBL report assurance statements: UK and European evidence', Managerial Auditing Journal, vol. 21, no. 4, pp. 329 - 71,

Edgley, CR, Jones, MJ \& Solomon, JF 2010, 'Stakeholder inclusivity in social and environmental report assurance', Accounting, Auditing \& Accountability Journal, vol. 23, no. 4, pp. 532-57,

Fedération des Experts Comptables Eurepéens 2003, Benefits of Sustainability Assurance, Brussels.

Fedération des Experts Comptables Européens 2006, IAASB Consultation Paper on Assurance Aspects of G3 - The Global Reporting Initiative's 2006 Draft Sustainability Reporting Guidelines, Bruxelles.

Frost, G \& Martinov-Bennie, N 2010, Sustainability reporting assurance: market trends and information content, CPA Australia Ltd, Victoria, Australia.

Futerra Sustainability Communications Ltd, Sustainability Ltd \& KPMG Global Sustainability Services 2010, Reporting Change: Readers \& Reporters Survey 2010.

Global Reporting Initiative 2011, Sustainability Reporting Guidelines, Amsterdam.

Hodge, K, Subramaniam, N \& Stewart, J 2009, 'Assurance of sustainability reports: Impact on report users' confidence and perceptions of information credibility', Australian Accounting Review, vol. 19, no. 3, pp. 178-94,

Hubbard, G 2009, Beyond Accounting, The University of Adelaide, Adelaide, Australia. 
Kim, D \& Nam, Y 2011, 'Corporate Relations with Environmental Organizations Represented by Hyperlinks on the \&It;i\&gt;Fortune\&lt;/i\&gt; Global 500 Companies' Websites', Journal of Business Ethics, pp. 1-13,

Kolk, A 2008, 'Sustainability, accountability and corporate governance: exploring multinationals' reporting practices', Business strategy and the environment, vol. 17, no. 1, pp. 1-15,

Kolk, A 2009, 'Trajectories of sustainability reporting by MNCs', Journal of World Business, pp. 367-74,

Kolk, A \& Perego, P 2010, 'Determinants of the adoption of sustainability assurance statements: an international investigation', Business strategy and the environment, vol. 19, no. 3, pp. 182-98, EBSCOhost, eoah, item: 20767011.

Kolk, A \& Van Tulder, R 2010, 'International business, corporate social responsibility and sustainable development', International Business Review, vol. 19, no. 2, pp. 119-25,

KPMG Global Sustainability Services 2008, International Survey of Corporate Responsibility Reporting 2008, Amstelveen.

KPMG Global Sustainability Services \& AccountAbility 2005, Assurance Standards Briefing - AA1000 Assurance Standard \& ISAE3000, Amsterdam.

KPMG Global Sustainability Services \& SustainAbility Ltd. 2008, Count me in: The readers' take on sustainability reporting, Amstelveen.

Laufer, W 2003, 'Social accountability and corporate greenwashing', Journal of Business Ethics, vol. 43, no. 3, pp. 253-61,

Manetti, G \& Becatti, L 2009, 'Assurance Services for Sustainability Reports: Standards and Empirical Evidence', Journal of Business Ethics, vol. 87, pp. 289-98,

McKinsey \& Company 2010, How companies manage sustainability.

Mock, TJ, Strohm, C \& Swartz, KM 2007, 'An examination of worldwide assured sustainability reporting', Australian Accounting Review, vol. 17, no. 41, pp. 67-77,

Moneva, J, Archel, P \& Correa, C 2006, 'GRI and the camouflaging of corporate unsustainability', Accounting forum, vol. 30, pp. 121-37,

Moneva, JM, Archel, P \& Correa, C 2006, 'GRI and the camouflaging of corporate unsustainability'. 
Moroney, R, Windsor, C \& Aw, YT 2011, 'Evidence of assurance enhancing the quality of voluntary environmental disclosures: an empirical analysis', Accounting \& Finance, pp. no-no,

O'Dwyer, B \& Owen, D 2005, 'Assurance statement practice in environmental, social and sustainability reporting: a critical evaluation', The British Accounting Review, vol. 37, no. 2, pp. 205-29,

Owen, D, Swift, T \& Hunt, K 2001, 'Questioning the Role of Stakeholder Engagement in Social and Ethical Accounting, Auditing and Reporting', Accounting forum, vol. 25, no. 3, pp. 264-82,

Owen, D, Chapple, W \& Urzola, A 2009, Key Issues in Sustainability Assurance, International Centre for Corporate Social Responsibility, London.

Park, J \& Brorson, T 2005, 'Experiences of and views on third-party assurance of corporate environmental and sustainability reports', Journal of Cleaner Production, vol. 13, no. 10-11, pp. 1095-106,

Perego, P 2009, 'Causes and Consequences of Choosing Different Assurance Providers: An International Study of Sustainability Reporting', Int. Journal of Management, vol. 26, no. 3,

Phatak, AV, Bhagat, RS \& Kashlak, RJ 2005, International management managing in a diverse and dynamic global environment, McGraw-Hill Irwin, Boston.

Ramus, CA \& Montiel, I 2005, 'When are corporate environmental policies a form of greenwashing?', Business \& Society, vol. 44, no. 4, pp. 377-414,

Rikhardsson, P, Andersen, R, Jacob, A \& Bang, H 2002, 'Sustainability Reporting on the Internet', Greener Management International, no. 40, pp. 57-75, EBSCOhost, bth, item: 12175451.

Romero, S, Ruiz, S \& Fernández-Feijóo, B 2010, 'Assurance Statement for Sustainability Reports: the Case of Spain', Proceedings of the Northeast Business \& Economics Association, pp. 105-12, EBSCOhost, bth, item: 56100828.

Seuring, S \& Müller, M 2008, 'From a literature review to a conceptual framework for sustainable supply chain management', Journal of Cleaner Production, vol. 16, no. 15, pp. 1699-710,

Simnett, R, Vanstraelen, A \& Chua, WF 2007, Assurance on sustainability reports: an international comparison.

Smith, J, Haniffa, R \& Fairbrass, J 2011, 'A Conceptual Framework for Investigating 'Capture' in Corporate Sustainability Reporting Assurance', Journal of Business Ethics, vol. 99, no. 3, pp. 425-39, EBSCOhost, bth, item: 59460159. 


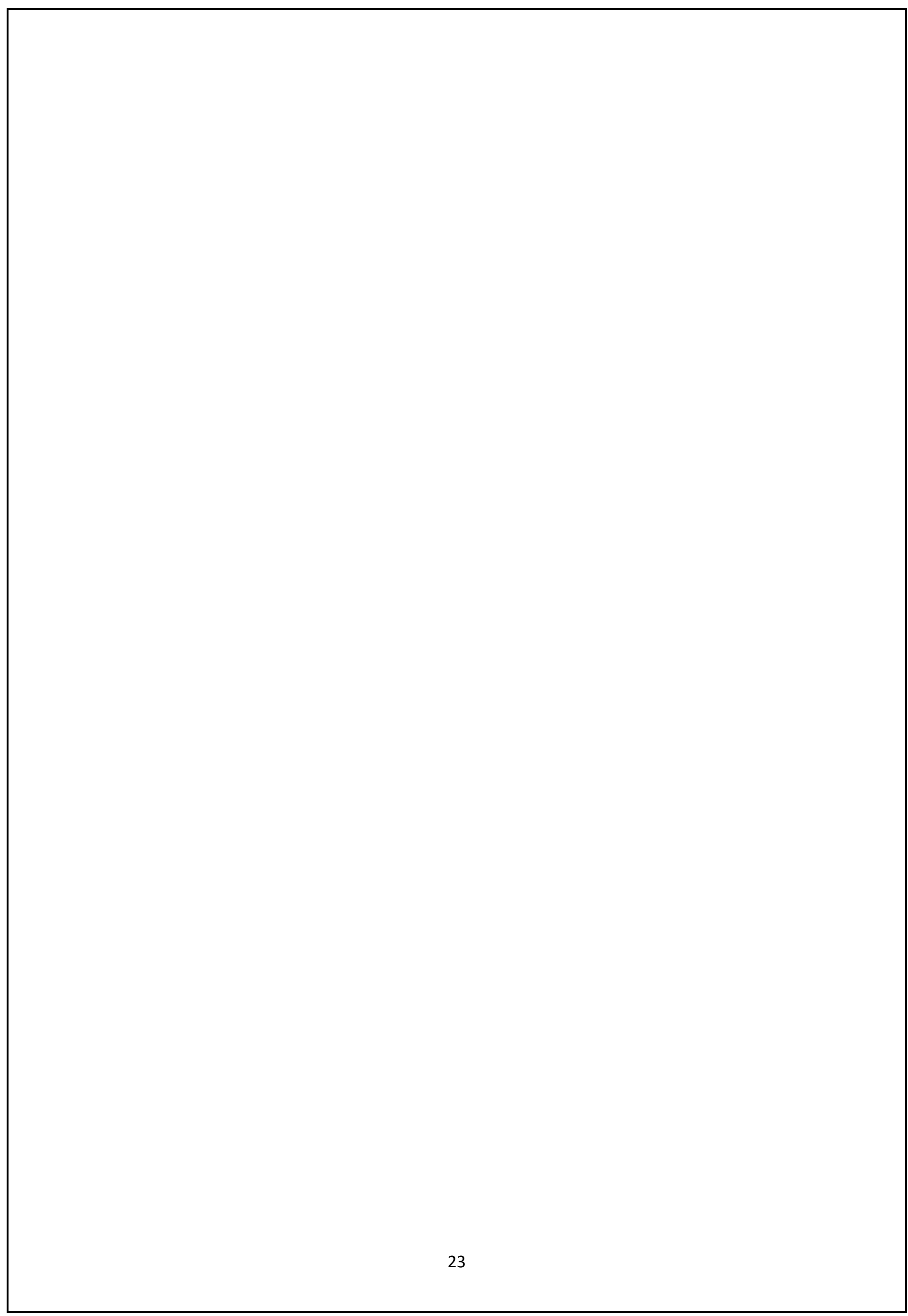

